\title{
REVIEW
}

\section{(Trans)forming the Colony}

\author{
Isabel Guzzardo-Tamargo \\ Rutgers University, US \\ isaguzz@gmail.com
}

Review of Raquel Salas Rivera, X/EX/EXIS: poemas para la nación/poems for the nation. Bilingual Press/Editorial Bilingüe, 2020. 97 pages.

Keywords: nationalism; trans; queer; bilingual; Puerto Rico

Language is a national passport. To not be mirrored in a language is to be denied entry into the nation. Raquel Salas Rivera's poetry collection, $X / E X / E X I S$, declares itself, in its subtitle, as "poemas para la nación/ poems for the nation." Specifically, these poems consider the role of language in queer and trans Caribbean futures. Caribbean feminism has long been concerned with sexual citizenship, ${ }^{1}$ that is, with how nationbuilding requires the naturalization of a cis-het citizen. Relatedly, queer scholars and activists critique how queerness in the Caribbean is often considered a foreign threat. ${ }^{2} X / E X / E X I S$ elucidates how this "foreignness" plays out linguistically, where languages deny the queer subject. Expanding on the heteronormativity of feminist and nationalist discourses, Salas Rivera writes queerness into a poetic language that denies the national romances embedded in Spanish and English.

I was lucky enough to attend the book presentation of $X / E X / E X I S$ at Betalocal in Viejo San Juan, Puerto Rico. Salas Rivera was not the only one to read that night; he read alongside a group of local poets, many of whom identify as queer and trans. The whole room radiated with cuir energy. An altar in memory of Alexa Negrón Luciano occupied one corner of the broad and airy space. Around this time, news of this transwoman's brutal killing was making headlines in Puerto Rico. Sure enough, Salas Rivera turned his book presentation into a celebration of queer and trans love and acceptance. Held by this energy, I heard the poem "notas sobre las temporadas/ notes on the seasons" and felt all of the hairs on my body raise.

In this poem, the speaker writes a letter to the lions in the Mayagüez zoo, located in Puerto Rico's west coast. The letter describes the lions' tactic of escape: transmogrification. However, as they turn from lion, to snake, to spider, their cages adapt with them. The speaker then establishes their shared experiences:

les escribí esta carta porque sé lo que es esperar la transmogrificación. les escribí esta carta porque sé lo que es esperar la transmogrificación. en cautiverio.

fuera de la pecera, hay un cuarto. fuera del cuarto, hay un zoológico. fuera del zoológico, hay un pueblo i wrote them this letter because $\mathrm{i}$ know what it's like to wait for transmogrification. i wrote them this letter because $\mathrm{i}$ know what it's like to wait for transmogrification in captivity.

outside of the fish tank, there is a room. outside of the room, there is a zoo. outside of the zoo, there is a

\footnotetext{
${ }^{1}$ Mimi Sheller utilizes the term sexual citizenship to indicate how gaining the status of the citizen depends on certain performances of gender, race, and sexuality. For more on this, see Citizenship from Below: Erotic Agency and Caribbean Freedom, Duke UP, 2012.

${ }^{2}$ For more on the association between queerness and foreignness see Makeda Silvera's "Man Royals and Sodomites: Some Thoughts on the Invisibility of Afro-Caribbean Lesbians," Feminist Studies, vol. 18, no. 3, 1992, pp. 521-532 and Thomas Glave's "Between Jamaica(n) and (North) America(n): Convergent (Divergent) Territories," Black Renaissance, vol. 6, no. 1, 2004, pp. 120-137.
} 
natal. fuera del pueblo natal, hay una colonia. fuera de la colonia, hay un imperio. fuera del imperio, vive el rey de las temporadas. si matas el rey, matas el juego. hometown. outside of the hometown, there is a colony. outside of the colony, there is an empire. outside of the empire lives the king of seasons. if you kill the king, you kill the game. ${ }^{3}$

Like many good poems do, "nota sobre las temporadas/notes on the seasons" leaves the reader with questions. Is it possible for Puerto Rico, this season-less land, to not play this game of endless captivity? Moreover, what does it mean to be queer in a colony, on this island that is already enclosed by water? Here the queer letter writer, perhaps more than other colonial citizens, understands the lion's predicament of adaptation and survival. In fact, in various poems, we see the queer speaker adjusting their body and posture, depending on the family member, town, and neighborhood. Thus, the collection relates the queer process of transitioning (from one gender/sex to another) to a capacity for radical, liberatory transmogrification. Yet, (trans)formation is not just a queer practice of empowerment, but also a tactic of oppression. In a world where cages are malleable, transformation is futile.

Salas Rivera's practice of translation adds to the theme of transmogrification. A political and aesthetic choice, Salas Rivera writes and recites poetry bilingually throughout his oeuvre. In this collection, as in others, he translates his writing and places the English and Spanish versions alongside each other. However, this collection moves beyond inter-linguistic translation to consider the difficulty of translation within the Spanish language. Specifically, many poems discuss how gender-inclusivity does not translate well into Spanish. As the previous poem's opening line states, "in Spanish, we don't occur naturally." The title, $X /$ $E X / E X I S$, refers to the " $\mathrm{x}$ " used in written Spanish to include diverse and non-binary genders. Yet, this infrequently used " $\mathrm{x}$ " is not a panacea. The collection includes many poignant musings on the limits of the Spanish language, such as this moment in the poem "la cortadura/the cut:"

caigo entre los brazos
de quienes me aman,
justo a tiempo,
y rechazo su amor
porque soy una malagradecida.
por una palabra/
partida/
en mitades
que no me completan,
por un pronombre,
un adjetivo.
los requisitos para ser amadx
son: ser amada.
nunca seré amada,
aunque me amen.
a los 18 años escribí por primera vez:
no me quiero así,
pero así me quieres.

\author{
i fall into the arms \\ of those who love me \\ just in time, \\ and reject their love \\ because i am ungrateful. \\ over a word/ \\ split/ \\ in halves \\ that don't complete me, \\ over a pronoun, \\ an adjective.
}

the requirements for being amadx are: being amada i'll never be amada, even if i'm loved.

for the first time, at 18, i wrote: $i$ don't want myself like this, but this is the way you love me*

* $i$ don't love myself like this, but this is the way you want me.

\footnotetext{
${ }^{3}$ Every poem in the collection is in Spanish and English.
} 
Ironically, in this poem about Spanish's inabilities, repetition is required in English to represent the double meanings of love and desire in the phrase "no me quiero así/pero así me quieres" that Spanish conveys. Thus, like the transmogrifying lions that encounter new cages in each switch, no language is neutral. In this poem, love and acceptance require uncomfortable linguistic contortions from queer subjects: being amada, instead of amadx. Language cuts and splices; each adjustment a wound queer people are forced to bear. However, in the collection, we also catch glimpses of hope that languages can be a home to the queer community: " $\mathrm{i}$ can forgive my mentors for never/telling me that in the end what we want is to be loved, how we could be/ as well as how we are, in both and all the languages we dream."

Linguistic inclusion becomes a tenuous goal when there is no nation to begin with, when the nation is a necropolis. A necropolis ${ }^{4}$ can come in many forms. It rears its ugly head when Puerto Ricans are left to die after hurricanes, when indebtedness determines one's right to live, when trans people are openly murdered. In $X / E X / E X I S$, I see the necropolis depicted metaphorically as a place ravaged by bombs that target writers and poems. Bombs are the conceit of the poem "cada traducción es una transformación/each translation is a transformation." These are the first and last stanzas:

la gente trans sabe que cada
transformación
es como si explotaran triquitraques
en nuestras venas acordeónicas
del ir y venir
de vecindarios y familias
más o menos escogidas
pero cuando sueltas una bomba
no quedan traducciones
antes o después

$[\ldots]$

las bombas son la medida de todo el dolor habido y por haber

las bombas no lloran

las bombas no escriben poemas

matan a generaciones de escritores

el gobierno las construye

este gobierno

las tira

\author{
trans people know that each \\ transformation \\ is as if they threw firecrackers \\ in our accordion veins \\ made of coming and going \\ from neighborhoods and families \\ that are more or less chosen \\ but when you drop a bomb \\ there are no translations \\ befores or afters \\ $[\ldots]$ \\ bombs are the measure of all \\ past and future pain \\ bombs don't cry \\ bombs don't write poems \\ they kill generations of writers \\ the government builds them \\ this government \\ drops them
}

Here the trans community and their routine, painful firecracker-transformations are perhaps the most knowledgeable citizens in a nation that deploys bombs and destruction. The poem's focus moves from trans people to writers, who are the government's primary victims. The collection's closing poem expands on this antagonism between the nation and the writer. In "una puerta que no cierra porque se expandió la madera/a door that won't close because the wood has expanded," a carpenter cuts down trees to build a country. The endangered trees hold words in their entrails, but the tree itself is a poem. Thus, the language that builds the nation is intrinsically anti-poetic. In the end, the speaker and someone called chlöe, perhaps a lover, fight back:

vinieron los hombres a jodernos la vida, y matar los poemas.

qué aborrecibles,

como los cargos

con sus emblemas, the men came to fuck with our lives, and kill the poems.

how abhorrent,

like cargos,

with their emblems,

\footnotetext{
${ }^{4}$ Achille Mbembé, in his famous essay "Necropolitics," explains that Western modernity defines sovereignty as the right to dictate who lives and who dies. He states that colonies are the necropolis par excellence: they are where the violence of the states operates, supposedly in service of "civilization." For more on Puerto Rico as a necropolis see Marisol LeBrón's book Policing Life and Death: Race, Violence and Resistance in Puerto Rico, University of California Press, 2019.
} 
pero, chlöe, los poemas son menos que nosotras, y más que el país por el cual son sacrificados.

volveremos a colgarlos de todas las ventanas, las piedras y los columpios: petroglíficos en el furor. but, chlöe, the poems are less than us, and more than the country for which they are sacrificed.

we will hang them again from the windows,

the stones, and the swings: petroglyphic in the fury.

Thus, chlöe and the speaker challenge the bombs and the carpenters, these national symbols and wielders of linguistic warfare. $X / E X / E X I S$ ends with this communal queer act of linguistic resistance, reminiscent of the book's presentation in Viejo San Juan, where poetry and prayers for Alexa hung in the air. Trans and queer writers are poised to (trans)form the nation; poetry and the queer, new languages that the collection imagines are one and the same. The final comparison of poetry to petroglyphs indicates the timelessness of queer languages. They are not "new" or "modern" or "foreign"-they have been here; the queer writer and reader can translate.

\section{Competing Interests}

The author has no competing interests to declare.

How to cite this article: Guzzardo-Tamargo, I 2021 (Trans)forming the Colony. Anthurium, 17(1): 5, 1-4. DOl: https://doi.org/10.33596/anth.435

Published: 01 September 2021

Copyright: ( 2021 The Author(s). This is an open-access article distributed under the terms of the Creative Commons Attribution 4.0 International License (CC-BY 4.0), which permits unrestricted use, distribution, and reproduction in any medium, provided the original author and source are credited. See http://creativecommons.org/licenses/by/4.0/. 